\title{
Parable to Paradigm to Ideology: Thinking through (the Jesuit) Theatre
}

\section{William Daddario}

\section{Parable/Paradigm/Ideology}

With this essay, I would like to present and analyze a paradigm of thought that I refer to as thinking through theatre. This paradigm first appeared to me in Maaike Bleeker's contribution to Laura Cull's edited collection Deleuze and Performance (2009). There, the paradigm provided Bleeker with the opportunity to develop key themes in Ivana Müller's 2004 performance How Heavy Are My Thoughts? through the philosophical lens of Gilles Deleuze and Félix Guattari's What Is Philosophy? (1994). For Bleeker, Müller's performance constituted an affective articulation of Deleuzio-Guattarian concepts and helped to elucidate the theatrical dimension of the French philosophers' dispositif. By the end of her article, Bleeker argues, "How Heavy Are My Thoughts? shows thinking in Deleuzian terms as something that happens 'in between': between people, and between people and the things they find themselves confronted with," while demonstrating that Deleuze and Guattari's philosophy constitutes a unique performance in and of itself. ${ }^{1}$

In what follows, I want to add a peculiar form of dramatic literature to the assemblage of performances and ideas created by Bleeker. By inserting the Jesuit Giovanni Domenico Ottonelli's Della Christiana Moderatione Del Theatro Libro (Florence, 1652) into that assemblage, I aim to construct a new analytic constellation consisting of Bleeker, Deleuze, Guattari, Müller, the seventeenth-century Jesuit priest, and, of course, myself. ${ }^{2}$ The addition of Ottonelli and his treatise opens the paradigm of thinking through theatre first surveyed by Bleeker onto a historical terrain where the "dramatic" component of the Jesuit's writing emerged, not through a traditional staged performance, but in the spiritual conversion of all who had strayed from the Church's embrace. As a Jesuit, Ottonelli concerned himself with helping each and every individual to perceive the path of salvation paved and preserved by the Jesuit Order, to practice a disciplined life of self-renunciation, and, ultimately, to see the world through the ideological aperture of the Catholic Faith enunciated by the Jesuit founder, Ignatius Loyola.

One parable, in particular, from Ottonelli's treatise reveals his creation as a work of dramatic literature: "Si narra la notabile conversione di uno scenico

\footnotetext{
Will Daddario was a visiting assistant professor at Gustavus Adolphus College in the fall of 2010, and will serve as an adjunct professor at the University of Minnesota and Augsburg College in the spring of 2011. This essay draws from research he executed while writing his dissertation, "Baroque Venetian Theatre: Dialectics of Excess and Discipline in the 16th and 17th Centuries." He received his doctorate from the University of Minnesota
} 
Sacerdote, per mezzo de gli esercitii spirituali di S. Ignatio Patriarca" ("The remarkable conversion of a scenic Priest, by means of the spiritual exercises of Saint Ignatius the Patriarch") allegorizes the Jesuit method of conversion by introducing a "scenic priest," who has strayed from his role of shepherd, into a sordid life bound up with the recitanti ("actors") and life-practices of other profane stage performers. Perceiving the errors of his ways, the scenic priest embarks upon a spiritual quest for rebirth by participating in the Spiritual Exercises, a ritual of spiritual contemplation designed by Loyola to turn one's gaze upon the self and to force a symbolic rebirth for those who had strayed from the Church. The "scenic" modifier of Ottonelli's priest contains a backward and a forward glance such that it refers both to his participation in the unholy domain of the recitanti and to his eventual status as a "virtuous actor" enscened by God within the Jesuit theatre of the world. The parable, then, enacts the individual performance of spiritual conversion through the character of the priest while it also instructs all who might read it to do the same.

By placing Ottonelli's parable within the critical constellation prepared by Bleeker, I intend to illustrate how the Jesuit author sheds his traditional appearance as a staunch antitheatricalist and begins to appear as a creator of affects, whose goal is a complete rewiring of individual subjectivity through the cultivation of a very specific type of acting. Reading Ottonelli alongside Deleuze, Guattari, and Bleeker helps to reveal the paradigmatic status of thinking through theatre within the Jesuit process of conversion. More than that, such a philosophical-historiographical reading suggests the presence of a theatrical ideology, not just within the Jesuit Counter-Reformation project but also within our own everyday lives. Thinking through the Jesuit theatre, an idea prepared by Ottonelli's parable when placed beside Deleuze and Guattari's philosophy, can lead to a self-reflexive analysis of the theatres through which we all think, thus forcing a confrontation in the present moment with all that conditions our individual processes of subject formation.

With this essay, I hope to provide a useful scaffold for future scholarship that applies Deleuzian philosophy to sixteenth- and seventeenth-century Italian theatre and culture. More generally, I intend to add to the growing body of philosophically engaged work within performance and theatre studies and to participate in the ongoing effort to rethink theatrical paradigms with the help of Deleuze's concepts. After briefly contextualizing Ottonelli and his work within the Jesuit Order of the seventeenth-century, I will unpack Bleeker's analysis of Deleuze and Guattari so as to evince from the Jesuit's work the consequences of thinking through theatre.

\section{Who Was Ottonelli?}

We know very little about Ottonelli. He was born c.1584 and died in Florence in 1670. Italian scholars and students of Jesuit history paint him in a stark light as an antitheatricalist concerned with the morally damning entertainment of theatrical 
performance in the seventeenth century. The most recent, concentrated survey of his life comes from Joseph Connors's essay, "Chi era Ottonelli?" ("Who was Ottonelli?") in which Connors dresses the Jesuit in his usual garb, so to speak. "Ottonelli," he writes, "does not appear as a theologian or as a writer, nor as 'the mythic Jesuit' that the theoreticians of art love to imagine, but as a man of action, a guerrilla waging war against the theatre, and especially against the role played by women." In this light, Ottonelli resembles Stephen Gosson and William Prynne, the fiercest critics of the English theatre of the time. "Prynne, like Ottonelli, was contrary to all the evils of society: dance, dice [gambling], comedies, lascivious pictures, licentious behavior, practical jokes, toasts [with alcohol], long hair, curls, country romances, effeminate music, etc., 'all of which are pagan pastimes." Connors goes as far as to make the equation, "Prynne is the English Ottonelli, and vice versa." 5

Evidence to support such a claim comes from the anecdotal evidence and archival scraps scattered throughout Italian literature and Jesuit historical sources. For example, "We spy [Ottonelli] in Catania in 1635, where he interrupted a comedy representing an obscene act." After he moved on from there, "We find him . . . in Palermo together with another Jesuit (G.B. Carminta) intent on condemning a poor actor to prison for having staged an obscene gesture." ${ }^{6}$ While stories like these certainly appear to support the title of antitheatricalist, I believe there is another picture of the roaming Jesuit worth developing.

This new image of Ottonelli emerges from the pages of his treatise that I introduced above: Della Christiana Moderatione Del Theatro Libro, detto L'Ammonitioni A'Recitanti, Per avvisare agni Christiano a moderarsi da gli eccessi nel recitare. The book's title spelled out its mission; namely, to admonish stage actors and to advise each Christian on the necessary means for moderating the excesses of theatrical performance. While the content of the book's admonishments and advice follows clearly from that title, its form presents several surprising maneuvers that, in the end, reveal the Jesuit's mission not to be the destruction of theatre but, rather, the construction of a new kind of acting. With this work, Ottonelli attempted to produce a new subjectivity, one that he called "il virtuoso Attore," or "the virtuous actor."

The "scenic priest" was the epitome of the virtuous actor. In the parable featuring that character, one finds that the ends of acting virtuously are not nearly as important as the means or the event of acting:

Quel, che Dio risguarda, e stima in noi altri in questa vita, (la qual tutta è, come una Rappresentatione, e Comedia, che finisce presto, e piacca à Dio, che non sia Tragedia) non è il personaggio, che rappresentiamo, mà come ciascuno, e quando si sia portato bene nel rappresentarlo. E questo è l'obligo nostro. 
"That with which God is concerned and that we should be concerned with in this life (that everything is like a Representation, a Play, that soon ends, and that it is not a Tragedy, thanks to God), is that it is not the character we represent, but how we represent it and that we represent it well. This is our obligation."'7

While the subjectivity of the virtuous actor consolidates the totality of a Jesuit worldview into a collection of gestures, a specific vocabulary, and a precise mode of thinking, Ottonelli's story focuses on the discipline needed to enact the gestures of the virtuous actor, the language required for speaking in accordance with the Word of God, and the impetus for spiritual retreat that guides stray sheep into the Spiritual Exercises. As the scenic priest models for his readers, the process of the Spiritual Exercises instructs one how to act virtuously and guides the actor into the interior of the Church and upon the holy stage where God exists as the sole spectator. I argue that, despite the ardent antitheatrical rhetoric of much of Ottonelli's treatise, his parable attempts to help all who encounter it to think through the Jesuit theatre of the world. That theatre of the world, or il teatro del mondo, houses the converted sheep that the Jesuits manage to refold into the interior of the Church.

Ottonelli's strategic adaptation of acting appears plausible when situated within the Society of Jesus's wider Counter-Reformation project, which frequently utilized theatre and public performances to effect conversion among the masses. ${ }^{8}$ If one removes Ottonelli's Della Christiana Moderatione Del Theatro from the constellation of antitheatrical literature, such as those produced by Gosson and Prynne, and places it, instead, beside the Ratio Studiorum or the chronicles of Juan Polanco, then the positive uses of theatre within the Jesuit Order begin to rise to the surface. ${ }^{9}$ The Ratio — essentially the blueprint for the Jesuits' academic programming in their schools - for example, explicates the specific uses for Aristotle's Poetics and Rhetoric within Jesuit training programs. ${ }^{10}$ Polanco's letters detail subjective transformations taking place in individuals who undergo the Spiritual Exercises, effectively offering numerous parallels to Ottonelli's scenic priest. ${ }^{11}$ When placed beside Ottonelli's tract, these Jesuit writings take on the appearance of scripts that prescribe real-life performances and, thus, appear as forms of dramatic literature as well as strictly pedagogical or historical documents.

Of these examples taken from this collection of Jesuit dramatic literature, however, I believe that Ottonelli's work stands out for its potent articulation of the steps required to act virtuously in the world. Thus, while the Jesuit Order sometimes found Ottonelli's tactics and treatises a bit extreme (going so far, at times, to dissuade him from publishing), I believe the guide to virtuous acting found in Ottonelli's parable of the scenic priest remains faithful to the ideological mechanisms produced by the Jesuits in their effort to subjectivize individuals within the Jesuit teatro del mondo. ${ }^{12}$ 
A careful analysis of Bleeker's essay and the theatrical act of thinking modeled by Deleuze and Guattari will help to make further sense of such ideological mechanisms.

\section{The Stage of Thought}

Bleeker finds the mode of thinking through theatre in Deleuze and Guattari's shift away "from an understanding of thinking focused on thought-content, towards a focus on the constellation of elements through which thinking proceeds, and from which what is thought emerges in relation to an 'I' as the subject of this thought."'13 Her purpose in acknowledging this shift is to elucidate a relationship between Deleuze and Guattari's notion of the "conceptual persona" and Ivana Müller's performance, whereas I intend to utilize her argument to view the emergence and instrumental use of theatrical thought in the Jesuit constellation, i.e., their teatro del mondo, or the "theatre of the world," created to house the converted. ${ }^{14}$ When inquiring into the latter, it is not important to ask what one thinks after being converted and placed within the Jesuit teatro del mondo; rather, the inquiry must uncover the conditions that make possible an "I" that acts as an identity for converted individuals to occupy. The "constellation" to which Bleeker refers exists in my argument as an assemblage of conceptual frames and affects that order the world for whosoever occupies the "I" produced by Ottonelli's script.

In Bleeker's words, Deleuze and Guattari's act of thinking through theatre follows from the recognition of thought as "an event in which a 'plane' sets the stage for the appearance of a persona, or figure of thought, as the vector of movements of thought taking shape through concepts (in the case of philosophy), compositions (in the case of art), or knowledge (in the case of science)." ${ }^{\prime 15}$ The function of the plane in the case of philosophy is to "acquire a consistency without losing the infinite into which thought plunges"; in the case of art, to express chaos through percepts and affects that become monuments capable of "confid[ing] to the ear of the future the persistent sensations that embody the event"; in the case of science, "to provide chaos with reference points." 16 In philosophy, art, and science, chaos conditions thought itself and, thus, appears as "a void that is not a nothingness but a virtual, containing all possible particles and drawing out all possible forms, which spring up only to disappear immediately, without consistency or reference, without consequence." 17

While much of What is Philosophy? theorizes the differences between the planes created by philosophy, art, and science, Deleuze and Guattari observe toward their conclusion that "there are also cases in which art, science and philosophy cannot be understood as distinct [from each other or] in relation to the chaos in which the brain plunges." ${ }^{18}$ To understand these indistinct relations, Bleeker directs her reader to three types of interferences, or zones of overlap, in which the planes opened by philosophy, art, and science blur into chaos: "extrinsic interference," which appears when each discipline "remains on its own plane and utilises its 
own elements," like when an artist uses an artistic mode of knowledge to grasp a philosophical concept; "intrinsic interference," which appears when, for example, concepts leave a plane of immanence (i.e., the plane unique to philosophy) and slip into an artistic sensation; and the "No," which is a nonlocalizable interference that is particularly difficult to perceive. ${ }^{19}$ Bleeker's point in evoking these three interferences is to develop Deleuze and Guattari's belief that chaos does and must exist within every ordered system. Of special interest to my argument is the third type of interference, the "No," which "is to be found where the planes confront chaos." ${ }^{20}$

Using the plane of composition unique to art's mode of thinking as a model, the "No" can be understood as a type of interference that is "distinct in relation to the cerebral plane [i.e., the thinking subject]" but is "no longer distinct in relation to the chaos into which the [thinking subject] plunges. ${ }^{.21}$ It is not merely the case that the "No" is linked to the plane of composition, as the plane's shadow and dialectical counterpart; rather, Bleeker points out that art needs its "No." Art, in other words, needs non-art "as that against which [it] come[s] into being." ${ }^{22}$ Non-art is the field of conditions that makes possible the emergence of art. Encompassing both art and non-art, the "No" is a zone of indeterminacy or of uncertainty that always accompanies the affects and percepts generated from the plane of composition through which individuals express the chaos of the world.

In the final stage of her analysis of Deleuze and Guattari's work, Bleeker reminds her reader that the "No" is not the chaos "through which each mode of thinking cuts its plane." In terms of art, philosophy, and science, "[t]his shadow is," rather, "to be found in how that from which they distinguish themselves (as 'that which they are not') relates to this chaos through which they cut their planes." Moreover, " $[t]$ his 'that which they are not' [is] already part of making sense of chaos; it is the 'No' these modes of thinking need at every moment of their becoming." ${ }^{23}$ Bleeker defines this "that which they are not" as theatricality, which calls to mind and forces one to contemplate the unseen apparatus that produces the constellation through which one thinks the world.

By defining theatricality as that which thought/art/science is not and as the constellation through which one thinks the world, Bleeker opens the door to an important spatial dimension within the act of thinking and the act of subject formation. With her essay as a lens, theatre becomes the machinery of the outside that conditions the inside. Theatre prepares the constellation of concepts and affects through which the world coheres ("adsorbs" in Deleuze and Guattari's words) and becomes thinkable, sensible, and knowable. This kind of theatre, she suggests, is "constitutive of modern thinking" and operates as a generative chaos that buzzes inaudibly as a silent, sonorous interference. This complex conception of theatre is important for an understanding of the Jesuit teatro del mondo because it highlights the crucial role of uncertainty and nonidentity, or differential ontology, that the 
Jesuits attempt to remove completely from the subjectivity of the converted.

\section{Thinking through the Jesuit Theatre}

I conceive the Jesuit teatro del mondo as a plane of composition produced by the Jesuits onto which converted Catholics stepped in order to learn the craft of the virtuous actors, so as to be viewed (enscened) and assessed by God and his shepherds. This plane of composition rendered intelligible the chaos of the world. It did this first by distinguishing itself from the outside world. Once distinguished as the teatro del mondo, or the stage to be inhabited by the virtuous actors, the profane world, with all its daily tasks, worries, anxieties, and states of affairs transformed into a general chaos that opposed the order of the interior of the Church. By entering upon the stage, the individual could rid his or her world of chaos, uncertainty, and indeterminacy. This, at least, summarizes the argument made by Ottonelli's parable of the scenic priest.

Tuning into the interference of the "No," however, as theorized by Deleuze and Guattari and explicated by Bleeker, helps to deconstruct the claim made by Ottonelli and the Jesuits that a life without chaos exists. Could the scenic priest, as the allegorical model of the penitent par excellence, ever escape the outside? Or did the outside, in fact, inhere within the scenic priest, even after his act of self-renunciation, as that which the scenic priest was not, as that from which he was always attempting to escape by leading the life of a virtuous actor? Prior to conversion, the priest attempted to immerse himself in the world of public theatre: commedia dell' arte and Carnevale entertainments organized by the leaders of Italian cities for the pleasure and (more frequently) pacification of the common people. By attending such affairs, the priest was engaged in a form of thinking through theatre, but, according to Ottonelli, the scenic priest was misleading himself. For the Jesuit author, the fascination with profane theatrical spectacle constituted the source of the foolishness (stoltezze) that distracted the scenic priest and kept him from enlightenment. To unfetter himself, the priest embarked upon the Spiritual Exercises in an attempt to acquire a true sense of order. The Jesuit theatre of the world promised the priest a true character, a subject position from which the chaos of the profane world would recede from view. I contend, however, that a crisis of the self emerges from that tension between the scenic priest and the "No," or his inhering that-which-he-was-not even as he attempted to expel it. The subjectivity of the scenic priest, and, by extension, of all Catholic converts participating in the Spiritual Exercises, was founded upon a gap within the self that opened during the regimented act of self-renunciation that led him to his public performance of repentance in front of the congregation.

This gap within the convert, however, presents two faces. From Bleeker's point of view, the gap is a necessary and unavoidable condition of consciousness, 
one that Müller attempts to explore with How Heavy Are My Thoughts? From Ottonelli's point of view, this same gap appears as that which one must fill or pave over in order to gain salvation. Bleeker's perspective and the philosophy of Deleuze and Guattari leads down a path that presents the practice of self-fashioning as the means for tuning into the interference of the "No" and integrating that frequency into one's sense of the self. ${ }^{24}$ Ottonelli also advocates a practice of self-fashioning, but it is the practice based on Jesuit ideology that substitutes self-renunciation for knowledge of the self. From both viewpoints, the question "How am I not myself?" plays a dominant role in navigating one's way through the chaos of the world. For Bleeker et al., it is a question prompting a kind of radical self-doubt capable of leading an individual to a renewed understanding of his or her self. For Ottonelli and the Jesuits, on the other hand, the same question functioned as a moral law mandating perpetual self-renunciation.

Once the moral exigency of self-renunciation replaced the quest for knowing and caring for the self, the individual negated the generative chaos that always existed as that which the individual was not, as the world against which the subject defined his or her self. Doing this, I suggest, rendered invisible the structures of seeing and knowing the world that shaped the subject's perceptions and affections. The ostensible benefit of the perspective presented by the Jesuit teatro del mondo was a removal of chaos from the subject. The Jesuit theatre framed chaos as an element of the old self that a subject could eject by undergoing the Jesuit brand of the care of the self. From that point on, the Church propped up the individual's subjectivity by creating for each virtuous actor a readymade vocabulary and series of gestures intended to articulate a belief in its one true God.

The Jesuits created their own theatre for individuals to think through. It became the constellation through which individuals apprehended and cognized the world. As opposed to the mode of thinking proposed by Bleeker's development of Deleuze and Guattari's philosophy in which a kind of radical nonidentity is forwarded as the marker of modern subjectivity, the Jesuits negated the negative, the chaos of the exterior, in the name of order. ${ }^{25}$ The Jesuit theatre was, in this light, an autonomous world that attempted to shut out the complexity of nonidentity with the facility of an identity crafted, in large part, through the Spiritual Exercises.

The crisis of the self, then, was not the knowledge that the self was truly reliant on the chaos of the exterior. The crisis did not consist in the individual's recognition that he or she was and was not his or her self. The crisis of the self emerged when that knowledge was labeled as an unnecessary component of thought. From the Jesuits' perspective, the teatro del mondo was the sole path capable of slicing through the chaos of life in the sixteenth and seventeenth centuries. As Ottonelli averred, the virtuous actor was the only subjectivity capable of accurately making sense of that chaos. In the final analysis, however, the virtuous actor contained a shadowy underside. "Virtuous actor" stood for a collective identity formed around 
a "No" that was sublated and replaced with the audibility of Catholic doctrine.

As such, Ottonelli's tract yields itself to precisely the type of historiographic analysis prepared by Michel de Certeau. ${ }^{26}$ It is an example of what de Certeau recognized as the construction of intelligibility through which "shards created by the selection of materials, remainders left aside by an explication[,] come back, despite everything, on the edges of discourse or in its rifts and crannies." ${ }^{27}$ Ottonelli's narrative constructs the black and white, before and after, foolish and enlightened character of the scenic priest but, in doing so, draws the eye to the lingering inherence of the "No" that the Jesuit practice of the self worked so hard to deny. Once visible, the "shards" of Ottonelli's negation of the "No" render the ostensibly sensible and ordered Jesuit theatre of the world as nonsensical and disordered. It was precisely disorder that the Jesuits inserted into the subjectivity of their converted flock by disavowing the generative chaos that Deleuze and Guattari theorized. The Jesuit teatro del mondo structured a sense of belonging around an invisible outside that the flock would always work so hard to renounce. The Jesuits enforced the disorder of the self attained through perpetual self-renunciation as an obligatory pleasure in lament. It was a peculiar pleasure taken in not knowing the self. The converted subjectivity did not have to know his or her self because the Church assumed that labor for the individual.

Ottonelli's parable of the scenic priest in particular and the entire treatise in general acts not only as the script but also as the rehearsal of the performance of everyday life mandated by the Jesuits. As a plane of composition, Ottonelli's stage presented a theatre capable of housing each and every individual, a space in which each individual could situate his or her self within the subjectivity of the virtuous actor. Beyond the language on the page, Ottonelli's images expressed a summons to the Church's interior through affects and percepts, the means of expression belonging to artistic praxis. The folding into spiritual retreat that Ottonelli presented with his narrative of the scenic priest should be read as a refolding into the interior of the Church, an act which attempted to pacify the chaos of the world but only supplanted the possibility of embracing chaos as a necessary "No" within any modality of thought. Forgetting or rejecting this knowledge of nonidentity, this question of "How am I not myself?" resulted in a crisis of the self. The collective subjectivity fashioned for the individual by the Jesuits presented a perspective onto the world, but the machinery facilitating that perspective was hidden from view and given intelligibility through the language of self-renunciation. Thus, the theatre of the world became, simply, the world.

\section{The Jesuit Theatrical Subject}

The subject position obtained through the Jesuit process of reform presents an intriguing extension of theatrical subjectivity in the sense of the word defined by Bleeker. She contends that 
Deleuze and Guattari's account of thinking suggests the possibility of conceiving of theatre in terms of thinking, where the theatre is not understood as a representation of thoughts, or processes of thinking, originating from subjects expressing their ideas through theatrical representations, but rather as a practice of thinking in which we, as audience, participate..$^{28}$

Müller's performance reveals to Bleeker that thinking is a positing of the self, but "the 'I' that emerges as the subject of our thoughts is not the self that does the positing. ${ }^{229}$ Turning from an aesthetic-philosophical analysis, such as that made by Bleeker, to a philosophical-historiographical critique of Jesuit subject formation, I believe that it is possible to locate the emergence of theatrical subjectivity in the West within Ottonelli's treatise. Unlike Müller, who is actively aware of and intent on investigating this theatrical subjectivity, Ottonelli's scenic priest receives his theatrical subjectivity as ready made. For the latter, it will always be impossible to tune into the generative chaos of the world because that chaos has been removed from his sight.

Faced with Ottonelli's parable and with the line of critique opened by Bleeker, the following question presents itself in the time and space of the now: Through what theatres do we think? What are the theatres that structure our thoughts? Attempting to answer those questions places the constellation of thought before one's eyes and presents the dual nature of historical inquiry. On the one hand, the theatre, dramatic literature, or performance that one thinks about exists as the object that one approaches with a specific critical methodology. On the other hand, there is always another theatre structuring the historical inquiry from its outset. This other theatre, the frame of one's thought, arises from the constellation of questions driving any critical analysis. Both the theatre in one's study and theatre of one's study must receive visibility; otherwise, the latter dissolves into background noise where it channels ideological presuppositions. The potency of Jesuit theatre, with its pedagogical and psychagogical power of subject transformation, demands a revisitation of the archives containing the traces of its historical endeavors. ${ }^{30}$ Perhaps by attempting to think through the mechanisms of Jesuit theatre we can also gain awareness of our own ideological tendencies.

\section{Notes}

1. Maaike Bleeker, "Thinking Through Theatre," Deleuze and Performance (Deleuze Connection Series), ed. Laura Cull (Edinburgh, Scotland: U of Edinburgh P, 2009) 157.

2. Giovanni Domenico Ottonelli, Della Christiana Moderatione Del Theatro Libro, detto L'Ammonitioni A'Recitanti, Per avvisare agni Christiano a moderarsi da gli eccessi nel recitare. Sono divise in tre brevi Trattati, ciò̀: Il Primo, intorno a' Recitanti; il secondo, intorno al Comico Beltrame, \& al suo libro; il terzo, intorno a'Ciarlatani (Firenze, 1652). 
3. Joseph Connors, "Chi era Ottonelli?" Pietro da Cortona. Atti del convegno internazionale Roma-Firenze, 12-15 novembre 1997, a cura di Christoph Luitpold Frommel e Sebastian Schütze (Roma: Electa, 1997) 29: "Ottonelli appare non come un teologo o come uno scrittore, non come 'il mite gesuita' che i teorici dell'arte amano immaginare, ma come un uomo d'azione, un guerrigliero in lotta contro il teatro, e specialmente contro il ruolo che vi ricoprivano le donne." All Italian translations in this article are mine unless cited otherwise.

4. 30: "Prynne, come Ottonelli, è contrario a tutti i mali della società: danze, dadi, commedie, pitture lascive, mode licenziose, trucchi, brindisi, capelli lunghi, riccioli, parrucche, pastorali amorosi, musiche effeminate, ecc., "tutti sono passatempi pagani."

5. 30: "Prynne è l'Ottonelli inglese, e viceversa." For portraits of Italian Jesuit antitheatricalist, see Michael Zampelli, S.J., “'Lascivi Spettacoli': Jesuits and Theatre (from the Underside)," The Jesuits II: Cultures, Sciences, and the Arts, 1540-1773, eds. John W. O'Malley, S.J., Gauvin Alexander Bailey, Steven J. Harris, T. Frank Kennedy, S.J. (Toronto: U of Toronto P, 2006) 550-72.

6. 29: "Lo sorprendiamo a Catania nel 1635, mentre fa interrompere una commedia dove si rappresentava un gesto osceno. Lo troviamo poi a Palermo insieme ad un altro gesuita (G.B. Carminta) intento a condannare un povero ciarlatano alla galera per avere messo in scena un gesto osceno."

7. Ottonelli 356.

8. For a general history offered from a Jesuit perspective, see John O’Malley, The First Jesuits (Cambridge: Harvard UP, 1993).

9. The Ratio Studiorum: The Official Plan for Jesuit Education, trans. Claude Pavur, S.J. (Saint Louis, MO: The Institute of Jesuit Sources, 2005); Year by Year with the Early Jesuits (1537-1556): Selections from the "Chronicon" of Juan de Polanco, S.J., trans. John Patrick Donnelly, S.J. (Saint Louis, MO: The Institute of Jesuit Sources, 2004). Polanco was the secretary of Ignatius Loyola, and in this volume one finds numerous mentions of the performative aspects of Jesuit sermons and the type of behavior instilled in practitioners of the Spiritual Exercises.

10. In Ratio Studiorum, see specifically "Rules for the Professor of Rhetoric" beginning on 155 .

11. In Year by Year, 9-10, Polanco writes the following: "Father [Pierre] Favre was at Worms and from there traveled to Speyer and finally to Regensburg, accompanying the court of Charles V. He did no preaching, but accomplished so much by the ministry of the sacraments of penance and the Eucharist, by holding private conversations, and, most important of all, by giving the Spiritual Exercises that Germans as well as Italians and Spaniards, even men outstanding for their authority, dignity, nobility, and learning, exerted themselves to change their lives. Some among them helped others through the same Spiritual Exercises. Among the others, [John] Cochlaeus stood preeminent for his fervor. As he used to say, he rejoiced that teachers of affectivity had been found."

12. See Connors 31 , where he relates that the Jesuits convinced Ottonelli not to publish his Trattato della pittura, e scultura as the third part in an entire series on the theatre.

13. Bleeker 157.

14. 150-51: "The conceptual persona is the 'I' that speaks through the philosophical speech act ... [It] is the 'I' that says 'I think therefore I am' and, in this way, founds the Cartesian cogito, with all the subjective assumptions constitutive of a science which is supposedly indifferent to consideration of the subject." In Müller's performance, a conceptual personal named "I.M." is constructed. "One might read the transformation of Ivana Müller into I.M. as the shift from Ivana Müller (as thinker/researcher aiming for true knowledge) to the Cartesian conceptual persona that speaks through her experiments and the kinds of conclusions she draws from them."

15. 157.

16. The first and third quotations come from Gilles Deleuze and Félix Guattari, What Is Philosophy?, European Perspectives, trans. Hugh Tomlinson and Graham Burchell (New York: Columbia UP, 1994) 42; the second from 176.

17. 118. For more on this concept of differential ontology see Gilles Deleuze, Difference and Repetition, trans. Paul Patton (New York: Columbia UP, 1994).

18. Bleeker 158 .

19. 158. Bleeker is drawing from Deleuze and Guattari 217-18.

20. 158 .

21. 158. See also Deleuze and Guattari 218.

22. 159 .

23. This and the preceding quotations in this paragraph come from Bleeker 159 . 
24. Here, I am hinting at a genealogy of spiritual exercises dating back to Plato that I articulate in my dissertation, "Baroque Venetian Theatre: Dialectics of Excess and Discipline in the Sixteenth and Seventeenth Centuries." Michel Foucault started a similar genealogy that covers the transformation of the spiritual exercises from Plato to the fourth century CE, a study that unfolds in the greatest detail in The Hermeneutics of the Subject. Lectures at the Collège de France, 1981-82, eds. Frédéric Gros, François Ewald, Alessandro Fontana, Arnold I. Davidson, trans. Graham Burchell (New York: Picador, 2005) and Security, Territory, Population. Lectures at the Collège de France, 1977-78, eds. Michael Senellart, François Ewald, Alessandro Fontana, and Arnold I. Davidson, trans. Graham Burchell (New York: Palgrave-Macmillan, 2007).

25. While outside the scope of the current essay, it is interesting to compare and contrast the differential ontology of Deleuze and Guattari with the negative dialectical mode of thinking produced by Theodor W. Adorno. See particularly, Theodor W. Adorno, Negative Dialectics, trans. E.B. Ashton (New York: Continuum, 2005) 5.

26. Michel de Certeau was himself a Jesuit. In my opinion, this makes his body of work all the more fascinating, and, perhaps, one can account for his self-reflexive historiographic operation by citing his lifetime devotion to the study of psychoanalysis.

27. Michel de Certeau, The Writing of History, trans. Tom Conley (New York: Columbia UP, 1988) 4 .

28. Bleeker 148.

29. 157.

30. The term comes from Foucault's Hermeneutics 407: 'Let us call 'pedagogical,' if you like, the transmission of a truth whose function is to endow any subject whatever with aptitudes, capabilities, knowledges, and so on, that he did not possess before and that he should possess at the end of the pedagogical relationship. If, then, we call 'pedagogical' this relationship consisting in endowing any subject whomsoever with a series of abilities defined in advance, we can, I think, call 'psychagogical' the transmission of a truth whose function is not to endow any subject whomsoever with abilities, etcetera, but whose function is to modify the mode of being of the subject to whom we address ourselves." 